\section{Ethylene Evolution by Tomato Plants Receiving Nitrogen Nutrition from Urea}

\author{
Allen V. Barker and Kenneth A. Corey \\ Department of Plant and Soil Sciences, University of Massachusetts, \\ Amherst, MA 01003
}

Additional index words. Lycopersicon esculentum, ammonium toxicity, plant nutrition, nitrification inhibitors, urease inhibitors, nitrapyrin, hydroquinone,

phenylphosphorodiamidate

Abstract. Urea fertilization of 'Heinz 1350' tomato (Lycopersicon esculentum Mill.) in sand or soil culture did not enhance ethylene evolution or restrict growth relative to plants receiving $\mathbf{N O}_{3}^{-}$, whereas $\mathbf{N H}_{4}^{+}$nutrition doubled the relative rates of ethylene evolution and restricted relative growth. Inhibitors of $\mathrm{N}$ transformations in media (nitrapyrin, Np; hydroquinone, HQ; and phenylphosphorodiamidate, PPD) had no apparent stimulator effects on ethylene evolution of plants grown on urea or $\mathbf{N O}_{3}^{-}$ nutrition in sand or soil. Ethylene evolution was enhanced by PPD relative to that by $\mathrm{Np}$ or HQ for plants receiving $\mathbf{N H}_{4}^{+}$nutrition. Each inhibitor had toxic effects on plant growth. Increasing $\mathrm{K}^{+}$supply from 0 to $8 \mathrm{~mm}$ in nutrient solutions decreased ethylene evolution and increased plant growth with urea fertilization. Urea had low phytotoxicity if its hydrolysis to $\mathbf{N H}_{4}^{+}$was prevented in the media. Chemical names used: p-dihydroxybenzene (hydroquinone); benzenephosphorodiamide (phenylphosphorodiamidate); 2-chloro-6-(trichloromethyl)pyridine (nitrapyrin).

Tomato plants grown withNH ${ }_{4}^{+}-\mathrm{N}$ nutrition develop a syndrome of disorders identified as $\mathrm{NH}_{4}^{+}$, toxicity (Maynard et al., 1966; Uljee, 1964; Wilcox et al., 1973). A characteristic of physiological stress from $\mathrm{NH}_{4}^{+}$ toxicity in tomato is evolution of ethylene at rates exceeding those of unstressed plants (Corey et al., 1987). In soil culture, the stress can be lessened by providingNH ${ }_{4}^{+}$-nourished plants with $\mathrm{K}^{+}$at molar equivalency to the $\mathrm{NH}_{4}^{+}$supply (Maynard et al., 1968; Barker and Lachman, 1986; Corey et al., 1987). In sand culture, in addition to adequate $\mathrm{K}^{+}$, buffering of the medium to a neutral $\mathrm{pH}$ is required to prevent $\mathrm{NH}_{4}^{+}$toxicity and elevation of ethylene evolution (Maynard and Barker, 1969; Corey and Barker, 1989).

Since urease activity by soil microorganisms releases urea-N as $\mathrm{NH}_{4}^{+}$, urea is an ammoniacal fertilizer, giving the possibility that its use may lead to $\mathrm{NH}_{4}^{+}$toxicity. It is not clear whether urea as such is phytotoxic. However, if the urea molecule is less toxic to plants than $\mathrm{NH}_{4}^{+}$, inhibition (Bremner and Douglas, 1971; Martens and Bremner, 1984) of the hydrolysis of urea may prevent or lessen its phytotoxicity.

In the present greenhouse study, ethylene evolution, as a measurement of plant stress, was determined for tomato receiving urea, $\mathrm{NH}_{4}^{+}$, or $\mathrm{NO}_{3}^{-}$nutrition. The effects of inhibitors of urease and vitrification and the

Received for publication 14 July 1989. Paper no. 2950 of the Massachusetts Agricultural Experiment Station. The cost of publishing this paper was defrayed in part by the payment of page charges. Under postal regulations, this paper therefore must be hereby marked advertisement solely to indicate this fact. effects of $\mathrm{K}^{+}$supply on ethylene evolution by plants on urea nutrition also were assessed.

In one experiment, 'Heinz 1350' plants established in soil culture were given $100 \mathrm{ml}$ $0.02 \mathrm{M}$ urea, $\left(\mathrm{NH}_{4}\right)_{2} \mathrm{SO}_{4}$, or $\mathrm{Ca}\left(\mathrm{NO}_{3}\right)_{2}$ daily for 3 weeks. Concurrently with this experiment, 'Heinz 1350' was grown with $0.02 \mathrm{M}$ urea in soil culture with two urease inhibitors (hydroquinone and phenylphosphorodiamidate) and a nitrification inhibitor (nitrapyrin) added individually to the urea solution at 10 mg.liter ${ }^{-1}$. In a second experiment, 'Heinz 1350' was grown for 4 weeks in sand culture using complete nutrient solutions (Hoagland and Arnon, 1950) with $210 \mathrm{mg} \mathrm{N} /$ liter from $\mathrm{NO}_{3}^{-}, \mathrm{NH}_{4}^{+}$, or urea in sand culture. Also in this experiment, 'Heinz 1350' was grown in sand culture using the same nutrient solutions with the two urease inhibitors and the nitrification inhibitor added individually at $10 \mathrm{mg} \cdot \mathrm{liter}^{-1}$. In a third experiment, 'Heinz 1350 ' was cultured in sand for 5 weeks, with $210 \mathrm{mg} \mathrm{N} /$ liter from urea and with $\mathrm{K}^{+}$progressively increasing from 0 to $8 \mathrm{~mm}$ (0 to $312 \mathrm{mg} \mathrm{K} /$ liter) in the nutrient solutions. In the experiments in sand culture, $100 \mathrm{ml}$ or more of nutrient solutions were added daily to displace solution held by the sand.

All experiments were conducted in a glasshouse with natural irradiance in Spring 1988 and 1989. Ethylene evolution was measured by sealing plants in bell jars and subsequently collecting samples of the atmosphere under the bell jars for analysis by gas chromatography (Corey et al., 1987). Acidity of the sand culture was determined electrometrically on aqueous eluates from the media at the end of the experiments. Ammonium- $\mathrm{N}$ and nitrate- $\mathrm{N}$ in eluates or soil samples were determined volumetrically
(Brenner, 1965) and electrometrically (Barker, 1971), respectively. Analyses of $\mathrm{Ca}, \mathrm{Mg}$, and $\mathrm{K}$ were by atomic absorption spectrophotometry (Barker and Corey, 1988). All experiments were factorial with all treatment combinations and were conducted in randomized, complete-block desires of four or five replications.

In sand culture, plants receiving urea nutrition had growth, expressed as dry weight of shoots, equal to that of plants on $\mathrm{NO}_{3}^{-}$and exceeding that of plants on $\mathrm{NH}_{4}^{+}$(Table 1). Lower leaves of plants grown on urea were slightly chlorotic, and plants grown on $\mathrm{NO}_{3}^{-}$lhad no symptoms of nutritional stresses. However, plants receiving $\mathrm{NH}_{4}^{+}$had chlorosis, necrosis, and cupping of laminae and produced ethylene at a rate exceeding that of the plants receiving urea orNO ${ }_{3}^{-}$. Amounts of $\mathrm{NH}_{4}^{+}$detected in the urea-based solution were not significantly different from those of the $\mathrm{NO}_{3}^{-}$-based solution. Plants fertilized with urea in soil-based media showed some indications of nutritional stresses. These plants had moderate leaf epinasty but no stem lesions associated with $\mathrm{NH}_{4}^{+}$toxicity (Barker et al., 1967). Urea nutrition produced slight but nonsignificant restrictions in shoot growth and a small, nonsignificant elevation in ethylene evolution relative to $\mathrm{NO}_{3}$-grown plants, whereas the effects due to $\mathrm{NH}_{4}^{+}$nutrition were significant (Table 2).

In sand culture, phenylphosphorodiamidate (PPD) inhibited plant growth relative to that obtained with nitrapyrin or hydroquinone (Table 3 ). The inhibition of growth by these chemicals was greater with urea or $\mathrm{NH}_{4}^{+}$than with $\mathrm{NO}_{3}^{-}$. The symptomatology for the plants receiving $\mathrm{NH}_{4}^{+}$could not be distinguished among the three inhibitors due to the dominance of $\mathrm{NH}_{4}^{+}$-toxicity symp-

Table 1. Growth and ethylene evolution by 'Heinz 1350 ' tomato grown on ammonium, nitrate, or urea in sand culture.

\begin{tabular}{lccc}
\hline \hline & \multicolumn{3}{c}{ Measurement } \\
\cline { 2 - 4 } $\begin{array}{l}\text { Form } \\
\text { of N }\end{array}$ & $\begin{array}{c}\mathrm{NH}_{4}-\mathrm{N} \text { in } \\
\text { eluate } \\
\left(\mathrm{mg} \cdot \mathrm{liter}^{-1}\right)\end{array}$ & $\begin{array}{c}\text { Shoot dry wt } \\
(\mathrm{g} / \mathrm{plant})\end{array}$ & $\begin{array}{c}\text { Ethylene } \\
\text { evolution } \\
\left(\mathrm{nl} \cdot \mathrm{g}^{-1} \cdot \mathrm{hr}^{-1}\right)\end{array}$ \\
\hline $\mathrm{NH}_{4}^{+}$ & $89 \mathrm{a}$ & $13 \mathrm{~b}$ & $35 \mathrm{a}$ \\
$\mathrm{NO}_{3}^{-}$ & $0 \mathrm{~b}$ & $21 \mathrm{a}$ & $13 \mathrm{~b}$ \\
Urea & $8 \mathrm{~b}$ & $20 \mathrm{a}$ & $16 \mathrm{~b}$ \\
\hline
\end{tabular}

${ }^{2}$ Means followed by different letters within columns are significantly different at $P \leq 0.05$, using Duncan's multiple range test.

Table 2. Growth and ethylene evolution by 'Heinz $1350^{\prime}$ tomato grown on ammonium, nitrate, or urea in soil culture.

\begin{tabular}{lccc}
\hline \hline & \multicolumn{3}{c}{ Mcasurement $^{2}$} \\
\cline { 2 - 4 } $\begin{array}{l}\text { Form } \\
\text { of N }\end{array}$ & $\begin{array}{c}\text { Stem lesion } \\
\text { rating }\end{array}$ & $\begin{array}{c}\text { Shoot } \\
\text { dry wt } \\
\text { (g/plant) }\end{array}$ & $\begin{array}{c}\text { Ethylene } \\
\text { evolution } \\
\left(\mathrm{nl}^{-} \cdot \mathrm{g}^{-1} \cdot \mathrm{hr}^{-1}\right)\end{array}$ \\
\hline $\mathrm{NH}_{4}^{+}$ & $3 \mathrm{a}$ & $6 \mathrm{~b}$ & $35 \mathrm{a}$ \\
$\mathrm{NO}_{3}^{-}$ & $0 \mathrm{~b}$ & $10 \mathrm{a}$ & $13 \mathrm{~b}$ \\
Urea & $0 \mathrm{~b}$ & $8 \mathrm{ab}$ & $16 \mathrm{~b}$ \\
\hline
\end{tabular}

${ }^{2}$ Means followed by different letters within columns are significantly different at $P \leq 0.05$, using Duncan's multiple range test. Stem lesion rating: $0=$ no lesions; $3=$ severe lesions. 
Table 3. Interactions and main effects of $\mathbf{N}$ form and chemical inhibitors of $\mathrm{N}$ transformation on growth and ethylene evolution by 'Heinz 1350 ' tomato grown in sand culture.

\begin{tabular}{|c|c|c|c|c|c|c|c|c|c|c|c|c|}
\hline \multirow{3}{*}{$\begin{array}{l}\text { Form } \\
\text { of } \mathbf{N}\end{array}$} & \multicolumn{12}{|c|}{ Measurement ${ }^{2}$} \\
\hline & \multicolumn{4}{|c|}{$\begin{array}{c}\mathrm{NH}_{4}^{+} \text {in eluate } \\
\left(\mathrm{mg} \cdot \text { liter }^{-1}\right)\end{array}$} & \multicolumn{4}{|c|}{$\begin{array}{c}\text { Shoot dry wt } \\
\text { (g/plant) }\end{array}$} & \multicolumn{4}{|c|}{$\begin{array}{c}\mathrm{C}_{2} \mathrm{H}_{2} \text { evolution } \\
\left(\mathrm{nl} \cdot \mathrm{g}^{-1} \cdot \mathrm{hr}^{-1}\right) \\
\end{array}$} \\
\hline & $\mathrm{Np}$ & $\mathrm{HQ}$ & PPD & Mean & $\mathrm{Np}$ & $\mathrm{HQ}$ & PPD & Mean & $\mathrm{Np}$ & $\mathrm{HQ}$ & PPD & Mean \\
\hline $\begin{array}{l}\mathrm{NH}_{4}^{+} \\
\mathrm{NO}_{3}^{-} \\
\text {Urea } \\
\text { Mean }\end{array}$ & $\begin{array}{r}102 \mathrm{~b} \\
1 \mathrm{a} \\
14 \mathrm{a} \\
39 \mathrm{a}\end{array}$ & $\begin{array}{r}128 \mathrm{a} \\
6 \mathrm{a} \\
6 \mathrm{a} \\
46 \mathrm{a}\end{array}$ & $\begin{array}{r}112 \mathrm{~b} \\
2 \mathrm{~b} \\
4 \mathrm{a} \\
41 \mathrm{a}\end{array}$ & $\begin{array}{r}114 \mathrm{a} \\
2 \mathrm{~b} \\
8 \mathrm{~b}\end{array}$ & $\begin{array}{r}9 \mathrm{a} \\
15 \mathrm{a} \\
15 \mathrm{a} \\
13 \mathrm{~b}\end{array}$ & $\begin{array}{l}10 \mathrm{a} \\
15 \mathrm{a} \\
17 \mathrm{a} \\
14 \mathrm{a}\end{array}$ & $\begin{array}{r}6 \mathrm{~b} \\
12 \mathrm{~b} \\
5 \mathrm{~b} \\
8 \mathrm{c}\end{array}$ & $\begin{array}{r}8 \mathrm{c} \\
14 \mathrm{a} \\
12 \mathrm{~b}\end{array}$ & $\begin{array}{r}.37 \mathrm{~b} \\
18 \mathrm{a} \\
20 \mathrm{a} \\
25 \mathrm{a}\end{array}$ & $\begin{array}{l}49 \mathrm{~b} \\
26 \mathrm{a} \\
13 \mathrm{a} \\
30 \mathrm{a}\end{array}$ & $\begin{array}{l}93 \mathrm{a} \\
18 \mathrm{a} \\
20 \mathrm{a} \\
45 \mathrm{a}\end{array}$ & $\begin{array}{l}60 \mathrm{a} \\
21 \mathrm{~b} \\
19 \mathrm{~b}\end{array}$ \\
\hline
\end{tabular}

zMeans for $\mathrm{N}$ form $\times$ inhibitor interaction (rows) and marginal means (main effects) are significantly different $(P \leq 0.05)$ if followed by different letters by Duncan's multiple range test. Abbreviations: $\mathrm{Np}$, nitrapyrin; HQ, hydroquinone; PPD, phenylphosphorodiamidate.

Table 4. Ethylene evolution by tomato plants grown in soil culture with urea and nitrification or urease inhibitors.

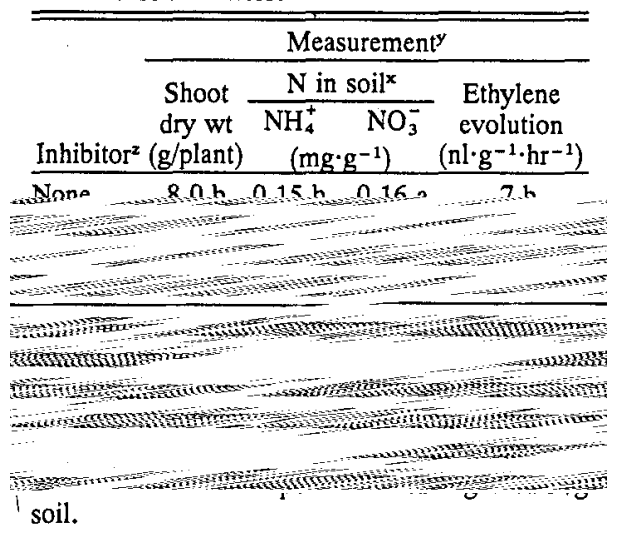

Table 5. Concentration of $\mathrm{K}$, dry weight, and ethylene evolution by shoots of 'Heinz 1350' tomato grown on urea nutrition with variable $\mathrm{K}$ levels in sand culture.

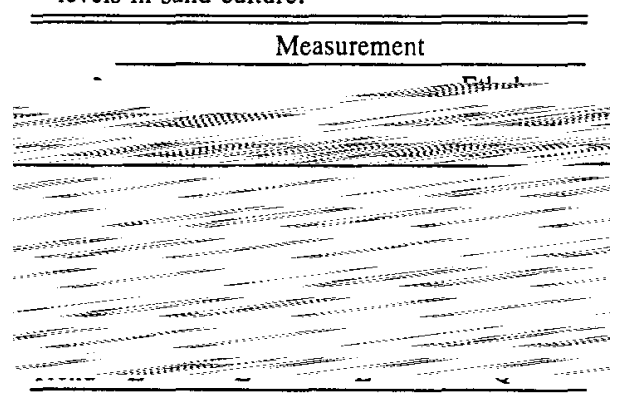

${ }^{2}$ Regression of measurement against $\mathrm{K}$ supply; $\mathrm{L}$, linear; $Q$, quadratic.

${ }_{*, * *} P \leq 0.05$ or 0.01 , respectively.

toms. With urea nutrition, plants receiving nitrapyrin had symptoms resembling incipient $\mathrm{NH}_{4}^{+}$toxicity, although littleNH ${ }_{4}^{+}(\approx 1$ $\mathrm{mm}$ ) accumulated in this solution, and the quantities accumulating were not significantly different from those of the other treatments with urea. Lower leaves of the plants receiving hydroquinone were chlorotic. Marginal necrosis or chlorosis occurred on the lower leaves of the plants receiving
Because of low microbiological activity in sand culture, conversion of urea to $\mathrm{NH}_{4}^{+}$was negligible. In soil-based media, urease activity may be sufficient to lead to $\mathrm{NH}_{4}^{+}$toxicity, although the toxicity was suppressed relative to that noted in cultures with $\mathrm{NH}_{4}^{+}$ alone. Chemical inhibition of urease stops $\mathrm{NH}_{4}^{+}$accumulation in media; however, chemicals used for this action should be evaluated for their phytotoxicity.

\section{Literature Cited}

Barker, A.V. 1971. Nitrate determinations in soil, water, and plants. Mass. Agr. Expt. Sta. Bul. 611.

Barker, A.V. and K.A. Corey. 1988. Ethylene evolution by plants under nutrient stress. HortScience 23:202-203.

$\mathrm{NO}_{3}^{-}$with nitrapyrin, hydroquinone, or PPD. Ethylene evolution was stimulated by PPD only for the plants receiving $\mathrm{NH}_{4}^{+}$. Urease activity in the nutrient solutions was apparently negligible. The lack of a significant difference in $\mathrm{NH}_{4}^{+} \quad$ concentration in the medium between nitrapyrin and hydroquinone or PPD supports this conclusion.

In soil culture, dry weights of shoots of plants receiving urea were affected only slightly by the inhibitors. Plants receiving PPD had severe foliar burn but no stern lesions. Plants grown with nitrapyrin developed severe stem lesions and twisting of the young foliage. Addition of hydroquinone had no effect on the appearance of the foliage, although severe stem lesions developed. Only the addition of PPD enhanced ethylene evolution relative to that of the plants receiving urea and no chemical inhibitor (Table 4).

Concentrations of $\mathrm{K}^{+}$in the shoots increased linearly as $\mathrm{K}^{+}$increased in the nutrient solution on sand culture (Table 5). Increases in dry weights of shoots accompanied increases in $\mathrm{K}^{+}$. Although already at relatively low levels, ethylene evolution by the shoots declined substantially when the concentration of $\mathrm{K}^{+}$reached $2 \mathrm{~mm}$ in the solution and $2 \%$ in the shoots. Shoot concentrations of $\mathrm{Ca}$ and $\mathrm{Mg}$ averaged $1.47 \%$ and $0.39 \%$, respectively, on a dry-weight basis, and were unaffected by $\mathrm{K}^{+}$supply. The acidity of the nutrient solution increased as $\mathrm{K}^{+}$increased in the solution. The $\mathrm{pH}$ decrease may have been due to plant absorption of $\mathrm{K}^{+}$and release of $\mathrm{H}^{+}$to maintain electrical neutrality in the solution. The increase in acidity did not promote phytotoxicity from urea. With $\mathrm{NH}_{4}^{+}$nutrition, declines in $\mathrm{pH}$ associated with absorption of $\mathrm{NH}_{4}^{+}$intensify the phytotoxicity of $\mathbf{N H}_{4}^{+}$(Barker et al., 1967). Enhanced phytotoxicity of $\mathrm{NH}_{4}^{+}$in acid media appears to be a unique interaction between form of $\mathrm{N}$ and $\mathrm{H}^{+}$concentration. Only traces of $\mathrm{NH}_{4}^{+} \quad$ were detected in the media in this experiment.

This research shows that urea has low phytotoxicity. Toxic effects of urea seem related to formation of $\mathrm{NH}_{4}^{+}$in the medium.
Barker, A.V. and W.H. Lachman. 1986. Potassium and ammonium interactions in nutrition of tomato cultivars and mutants. J. Plant Nutr. 9:121.

Barker, A.V., R.J. Volk, and W.A. Jackson. 1966. Growth and nitrogen distribution patterns in bean plants (Phaseolus vulgaris L.) subjected to ammonium nutrition: I. Effects of carbonates and acidity control. Soil Sci. Soc. Amer. Proc. 30:228-232. man. 1967. Induction of tomato stem and leaf lesions, and potassium deficiency, by excessive ammonium nutrition. Soil Sci. 103:319-327.

Bremner, J.M. 1965. Total nitrogen. Agronomy 9:1149-1178.

Bremner, J.M. and L.A. Douglas. 1971. Inhibition of urease activity in soils. Soil Biol. Biochem. 3:297-307.

Corey, K.A. and A.V. Barker. 1989. Ethylene evolution and polyamine accumulation by tomato subjected to interactive stresses of ammonium toxicity and potassium deficiency. J. Amer. Soc. Hort. Sci. 114:651-655.

Corey, K.A., A.V. Barker, and L.E, Craker. 1987. Ethylene evolution by tomato plants under stress of ammonium toxicity. HortScience 22:471-473.

Hoagland, D.R. and D.L Amon. 1950. The waterculture method for growing plants without soil. Calif. Agr. Expt. Sta. Circ. 347.

Martens, D.A. and J.M. Bremner. 1984. Effectiveness of phosphoroamides for retardation of urea hydrolysis in soils. Soil Sci. Soc. Amer. J. 48:302-305.

Maynard, D. N., A.V. Barker, and W.H. Lachman. 1966. Ammonium-induced stem and leaf lesions of tomato plants. Proc. Amer. Soc. Hort. Sci. 88:516-520.

Maynard, D. N., A.V. Barker, and W.H. Lachman. 1968. Influence of potassium on the utilization of ammonium by tomato plants. Proc. Amer. Soc. Hort. Sci. 92:537-542.

Uljee, A.H. 1964. Ammonium nitrogen accumulation and root injury to tomato plants. New Zealand J. Agr. Res. 7:343-356.

Wilcox, G.E., J.E. Hoff, and C.M. Jones. 1973 Ammonium reduction of calcium and magnesium content of tomato and sweet corn leaf tissue and influence on incidence of blossom end rot of tomato fruit. J. Amer. Soc. Hort. Sci. 98:86-89.
Barker, A.V., D.N. Maynard, and W.H. Lach- 